\title{
Música no ar... Cachoeira, Santa Maria, Morro Alto e Saltinho. Teixeira Vilela, Hercule Florence e Carlos Gomes, Campinas, século XIX'
}

\section{Maria Alice Rosa Ribeiro ${ }^{2}$ \\ Lenita Waldige Mendes Nogueira ${ }^{3}$}

RESUMO: A descoberta de que o maestro compositor Carlos Gomes escreveu peças para piano com os nomes de engenhos e fazenda de propriedade da família Teixeira Vilela, grandes proprietários de terras e escravos de Campinas, nos incentivou a escrever este artigo. Uma das propriedades, o engenho Santo Antonio da Cachoeira, foi imortalizada também pelas pinturas de Hercule Florence. $\bigcirc$ objetivo deste artigo é descrever as propriedades açucareiras e cafeeiras homenageadas pelo maestro compositor e pelo pintor, com base nos inventários post mortem; resgatar o papel da família dos proprietários na fundação e no desenvolvimento de Campinas açucareira e cafeeira; refletir sobre relações sociais e de amizade entre as famílias Teixeira Vilela, Florence e Gomes; estudar, com base nas partituras, a composição musical criada por Carlos Gomes. E, dessa forma, contemplar a história social e econômica - engenhos açucareiros, fazendas cafeeiras -, as artes plásticas e a música em Campinas do século XIX. PALAVRAS-CHAVE: Engenhos de Açúcar. Fazenda de Café. Escravos. Família Teixeira Vilela. Hercule Florence. Carlos Gomes. Campinas.

ABSTRACT: The finding of a set of musical scores composed by master composer Carlos Gomes, named after the Teixeira Vilela family sugar mills and coffee farms, stimulated us to write this article. The Teixeira Vilela were important proprietors of land and slaves in Campinas. One of the family's sugar mills, the engenho Santo Antonio da Cachoeira was also immortalized in Hercule Florence's paintings. The article aims at describing, based on post mortem inventories, the sugar and coffee properties the master composer and the French painter paid homage to; recovering the role of the proprietor's family in the foundation and development of Campinas; reflecting the social relationships of the families Teixeira Vilela, Florence and Gomes; based on musical scores, the musical opus composed by Carlos Gomes. Hence, the article involves Social and Economic History, Arts and Music, in nineteenth century Campinas.

KEYWORDS: Sugar Mills. Coffee Farm. Slaves. Teixeira Vilela Family. Hercule Florence. Carlos Gomes. Campinas.
1. À Maria Carolina Bovério Galzerani (in memoriam).

2. Professora Adjunta, Livre-Docente aposentada, Faculdade de Ciências e Letras da UNESP, Campus de Araraquara, SP; Pesquisadora Colaboradora do Centro de Memória CMU, UNICAMP, Campinas. Email: $<$ mariaalicerosaribeiro@gmail.com>.

3. Professora do Departamento de Música do Instituto de Artes, UNICAMP, Campinas. Email $<$ lwmn@iar.unicamp.br> 
4. A grafia antiga de Cachoeira era Caxoeira. Manteremos a grafia apresentada no documento original.

5. Cf. Correio Popular (2014, p. C1).

6. Adotamos a grafia Vilela. Porém, encontramos na documentação diferentes formas de grafar - Villela, Villella e Vilella. Manteremos a grafia constante nos documentos transcritos.

7. Em conversa com o pianista Fernando Lopes, ele comentou que Carlos Gomes gostava de presentear "os amigos de Campinas" com peças musicais ou dedicatórias. Porém, a relação precisa das composições com as propriedades, ele desconhecia. As peças para piano escritas por Carlos Gomes foram encontradas por Benedito Barbosa Pupo na Biblioteca Nacional. Essas composições eram pouco conhecidas, pois o compositor notabilizou-se pela obra operística. Em 1981, Fernando Lopes gravou para a Funarte o CD O piano 'brazileiro' de Carlos Gomes, no qual estão peças para piano, quadrilhas, polcas, valsas e outros gêneros de música de salão do século XIX, aquelas descobertas por Benedito Barbosa Pupo. Há uma excelente nota explicativa no encarte do CD, escrita por Bruno Kiefer. Na gravação constam as peças aqui comentadas
Introdução

A ideia deste artigo surgiu da notícia publicada no caderno cultural do jornal Correio Popular, de Campinas, que anunciava o próximo concerto da série Recitais da Academia Campineira de Letras e Artes (ACLA), de 2014, com a apresentação do pianista Fernando Lopes interpretando a obra do maestro compositor Antonio Carlos Gomes (Campinas, 1836 - Belém, 1896). Era setembro, e em Campinas comemora-se o mês de Carlos Gomes, o compositor nascido na cidade, filho do mestre-de-capela da matriz velha, Manoel José Gomes (Santana de Parnaíba, 1792 - Campinas, 1868), e irmão de outro músico não menos conhecido, José Pedro de Sant'Anna Gomes (Campinas, 1834 - 1908). No programa escolhido por Fernando Lopes constavam as peças musicais Caxoeira ${ }^{4}$, Santa Maria, Morro Alto e Saltinho, Uma paixão amorosa, Anemia, Preludietto, Quadrilha brasileira, A Cayumba, Bananeira, Quingombôs.

Quatro - Cachoeira, Santa Maria, Morro Alto e Saltinho - chamaram nossa atenção, pois elas tinham o nome das propriedades açucareira e cafeeira de Antonio Manoel Teixeira (Pitangui, 1795 - Campinas, 1850) e de seu filho Francisco Teixeira Vilelab (Campinas, 1829 - Campinas, 1873).

A ligação entre as composições musicais e as propriedades agrícolas era desconhecida ${ }^{7}$ e acendeu a nossa curiosidade. $\bigcirc$ que levou Carlos Gomes a intitulá-las com os nomes daquelas propriedades?

Além da amizade que aproximou o senhor de engenho e seu filho do mestre-de-capela e de seus filhos músicos compositores, o que naquelas propriedades com mais de 300 escravos inspirou Carlos Gomes? Que fragmentos da paisagem das lavouras de cana e café deixaram marcas naquelas composições? $\bigcirc$ que, do movimento repetitivo e monótono da roda da moenda, quebrado pela chegada das tropas de muares e pelas fumaças das chaminés, agitadas pelos ventos, poderia ter inspirado o jovem compositor?

Na primeira parte do artigo, o propósito é descrever as propriedades campineiras dos tempos do açúcar e do café e narrar as atividades desenvolvidas por dois personagens atuantes nas sociedades campineira e paulista: o senhor de engenho e comendador Antonio Manoel Teixeira e seu filho, cafeicultor e também comendador Francisco Teixeira Vilela. Um destaque especial acabou sendo emprestado ao engenho Santo Antonio da Cachoeira, uma vez que ele chegou até nós imortalizado pelas pinturas do artista Hercule Florence. Dos engenhos do Saltinho e Morro Alto, implantados por Antonio Manoel, nos anos de 1830, não restaram imagens. Podemos fazer uma vaga ideia de como eram pelas informações contidas nos inventários dos seus antigos proprietários. Da fazenda Santa Maria, a sede chegou até nós. Implantada por Francisco, entre 1853 e 1856, tornou-se uma das maiores propriedades cafeeiras da região de Campinas, segundo informações encontradas no inventário de seu proprietário e na classificação dos proprietários feita pela Câmara de Campinas, em 1872, para a cobrança da contribuição para as obras da matriz nova (catedral). Francisco Teixeira Vilela foi 
classificado na lista dos lavradores contribuintes do imposto na última classe, $11^{a}$. Os integrantes dessa classe, apenas dois, deveriam pagar a maior contribuição anual da ordem de Rs 1:000\$000 (um conto de réis), por serem os maiores produtores do município, colhendo entre 25 mil a 30 mil arrobas de café, açúcar ou algodão ${ }^{8}$. Depois da morte de Francisco, a antiga propriedade passou por diversas divisões e desmembramentos. Hoje, a sede construída por volta de 1868 encontra-se preservada, com algumas adaptações, em uma área total em torno de 29 alqueires $^{9}$.

Na segunda parte, o desafio é trazer ao leitor uma apreciação musical das peças Caxoeira, Santa Maria, Morro Alto e Saltinho. O que inspirou Carlos Gomes na elaboração das peças? A exuberância da cachoeira do rio Jaguari no encontro com o rio Atibaia para formarem o Piracicaba, a faina dos escravos ou a paisagem das matas em contraste com a uniformidade das lavouras? Como Carlos Gomes concebeu o estilo de forma a manter as quatro fazendas reunidas, marcando suas diferenças, mas dentro de uma mesma composição musical?

A aproximação da família Teixeira Vilela com a família Gomes não se restringiu a essas composições. Sant'Anna Gomes compôs uma peça especialmente para ser tocada pela banda de escravos da fazenda Santa Maria na inauguração da estação da estrada de ferro da Cia. Paulista em Campinas, em 1872, intitulada de forma simples A estrada de ferro. Até o momento essa peça não foi localizada.

Engenhos de açúcar e fazendas de café de Campinas no século XIX imortalizados por Hercule Florence e Carlos Gomes

Em 1850, quando do falecimento de Antonio Manoel Teixeira, os engenhos Cachoeira, Morro Alto e Saltinho tinham, respectivamente, 223, 76 e 56 escravos, 355 no total. Uma escravaria expressiva, também, encontramos no inventário do seu único filho e herdeiro universal, Francisco Teixeira Vilela, em 1873: a fazenda Santa Maria, com 800 mil pés de café e 339 escravos, e a Morro Alto, com seus 200 mil pés de café e engenho e 98 escravos.

Que personagens foram o senhor de engenho Antonio Manoel Teixeira e seu filho, Francisco Teixeira Vilela?

Antonio Manoel pertencia a uma das primeiras famílias, Teixeira Vilela - Teixeira Nogueira, a migrar de Baependi, Minas Gerais, para a recém-criada freguesia de Nossa Senhora da Conceição das Campinas do Mato Grosso de Jundiaí, até então bairro de Jundiaí, em 1774. Permanecendo na freguesia, a família tornou-se uma das mais atuantes na vida econômica e política da província. Ao longo de sua história, membros da família, principalmente Felipe Néri Teixeira (Carrancas, 1754 - Campinas, 181 2), Joaquim José Teixeira Nogueira (Lavras, 1759 - Campinas, 1832) e Manoel Teixeira Vilela (Lavras, 1752 - Campinas, 1820) atuaram como administradores públicos, ocupando cargos de capitão agregado, guarda mor, sargento mor, juiz ordinário, juiz de órfãos, intendente e
8. Na $11^{\text {a }}$ classe, além de Francisco, constava apenas o Barão de Limeira, Vicente de Sousa Queiroz (1813-1872), filho do Brigadeiro Luis Antonio de Sousa e de d. Genebra de Barros Leite. Ambos eram os maiores produtores de Campinas. A safra de café da Santa Maria 1874/75 foi estimada em 50 mil arrobas. Ver Maria Alice Rosa Ribeiro (2016a, p. 204).

9. Em outubro de 1873 , quando do falecimento de Francisco, a construção da sede não havia sido concluída, conforme o inventário. A informação é da área atual e foi fornecida pelo atual proprietário, Dr. Heitor Ulson, a quem agradecemos pelas informações sobre a fazenda e pela generosidade com que sempre nos recebeu. 
10. Demolida para ampliação da Avenida Francisco Glicério, localizada no centro da cidade.

11. Descendentes da família encontram-se ainda hoje na região de Campinas, Arthur Nogueira e Cosmópolis, ligados à produção de açúcar e etanol (Usina Ester), aos meios de comunicação (EPTV Campinas, filiada da Rede Globo) e outras atividades. Inventário e testamento de Antonio Manoel Teixeira. Proc. 2899, $1^{\circ}$. Of., 1850. Inventário do Comendador Francisco Teixeira Vilella. Proc. n. 4359, $1^{\circ}$. Of., 1873. Ver Celso Maria de Mello Pupo (1969, p.44 -53 e 227-232); Maria Alice Rosa Ribeiro (2015, p.541543 e 2016a, p. 200).

12. Ver Peter L. Eisenberg (1989, p. 317-369); Valter Martins (1996, p. 123-163); José do Amaral Lapa (1996, p. 85-163); Sergio Milliet (1982, p. 11-32 e 42-48), Paulo Eduardo Teixeira (2011, p.155-243).

13. No recenseamento de 1818 , o guarda mor foi registrado com uma produção de 3.000@ de açúcar e 49 escravos. Há uma discrepância entre os dados do Maço de População de 1818 e os do inventário de bens rústicos do mesmo ano. O sócio de Manoel era irmão do Brigadeiro Luiz Antonio de Sousa e pai de Francisco Ignácio, líder do movimento Bernarda de Francisco Ignácio. Ver Maria Alice Rosa Ribeiro (2015, p. 536-538). vereadores da freguesia (1774-1797), da Vila de São Carlos (1797-1842) e da cidade de Campinas (1842). Receberam terras de sesmarias. Foram "fundadores de igrejas", construíram a matriz velha, atual Basílica Nossa Senhora do Carmo, a matriz nova, Catedral, e a lgreja do Rosário ${ }^{10}$. Três dos seus membros foram religiosos: frei Antonio de Pádua (Baependi, 1743 - Itu, 1805), primeiro vigário, rezou a primeira missa por ocasião da criação da freguesia em 1774; padre José Teixeira Vilela Nogueira (Baependi, 1750 - Campinas, 1827), vigário de vara; e o padre Antonio Joaquim Teixeira Nogueira (Campinas, 1793 - Campinas, 1828), construtor e pároco da lgreja do Rosário ${ }^{11}$.

De início, a família estabeleceu-se como produtora de alimentos destinados ao abastecimento dos mercados local e regional de ltu, Jundiaí, Sorocaba e sul de Minas, por meio de tropeiros. Mas nos anos 1790, a crise no mercado mundial do açúcar, motivada pela revolta escrava de São Domingos, desorganizou a oferta do produto e elevou seus preços, o que mudaria completamente a economia de São Paulo e a inserção da família Teixeira Vilela Teixeira Nogueira na economia da freguesia das Campinas. A elevação dos preços do açúcar tornou possível economicamente a lavoura de cana e a fabricação do açúcar em terras distantes do porto de exportação de Santos. A concessão de terras de sesmarias viabilizou a grande propriedade açucareira e os recursos acumulados no comércio de abastecimento dos mercados locais financiaram as compras de escravos. A família Teixeira Vilela - Teixeira Nogueira foi beneficiada com a concessão de sesmarias e tornou-se uma das principais famílias no desenvolvimento da cultura canavieira e do engenho em Campinas ${ }^{12}$.

Nos fins do século XVIII, quando Manoel Teixeira Vilela, pai de Antonio Manoel, chegou à promissora vila de São Carlos vindo de Pitangui, Minas Gerais, encontrou não somente seus irmãos mais novos bem estabelecidos como senhores de engenho, como também um solo fértil para amealhar a própria riqueza. A princípio, produziu cana em sociedade com os irmãos, Felipe Néri e Joaquim José, mas logo abriu seu próprio engenho. $O$ inventário de bens rústicos da Vila de São Carlos, de 1818, registrou Manoel Teixeira Vilela como guarda mor e senhor de engenho, tendo como sócio no engenho Boa Vista, com 26 escravos, o Coronel Francisco Antonio de Sousa Queiroz ${ }^{13}$.

Em 1820, após o falecimento de seus pais, Antonio Manoel investiu sua herança na construção do engenho Santo Antonio da Cachoeira. Em poucos anos, acumulou grande patrimônio, como evidenciou seu testamento datado de 1833, no qual declarava ter engenho $e$ "[...] os escravos existentes estão lançados os nomes no livro grande todos juntos, entrando menores, formam o número de 230 escravos [...]". No século XIX, até a década de 1870, a maior riqueza dos grandes proprietários rurais era a escravaria, mais valiosa até mesmo que terras, plantações e as edificações do próprio engenho. Portanto, Antonio Manoel possuía um patrimônio imenso em escravos, $48 \%$ da riqueza bruta ou $94 \%$ da líquida. Além do engenho da Cachoeira, possuía os engenhos Morro Alto e Saltinho, sendo este último herdado de sua mãe. Os engenhos localizavam-se às margens dos rios 
Atibaia e Jaguari, onde ambos se aproximam para formarem o rio Piracicaba. $\bigcirc$ engenho Cachoeira ficava, segundo Hercule Florence, a 5 léguas a noroeste da Vila de São Carlos.

Hercule Florence (Nice, 1804 - Campinas, 1879)14 conviveu com Antonio Manoel. Visitou algumas vezes o engenho da Caxoeira, o que bastou para que o pintor o eternizasse nas aquarelas e nos traços a lápis ou a crayon da paisagem, da moenda, do engenho e dos escravos.

Em 1835, Florence fez um esboço da paisagem ocupada pela propriedade: ao fundo, matas; no centro, plantações de cana, casa de morada, engenho e senzala; à esquerda, um talhão já de café, representado por minúsculos pontinhos enfileirados; em primeiro plano, capins desordenados serpenteavam o caminho que conduzia à propriedade (Figura 1).

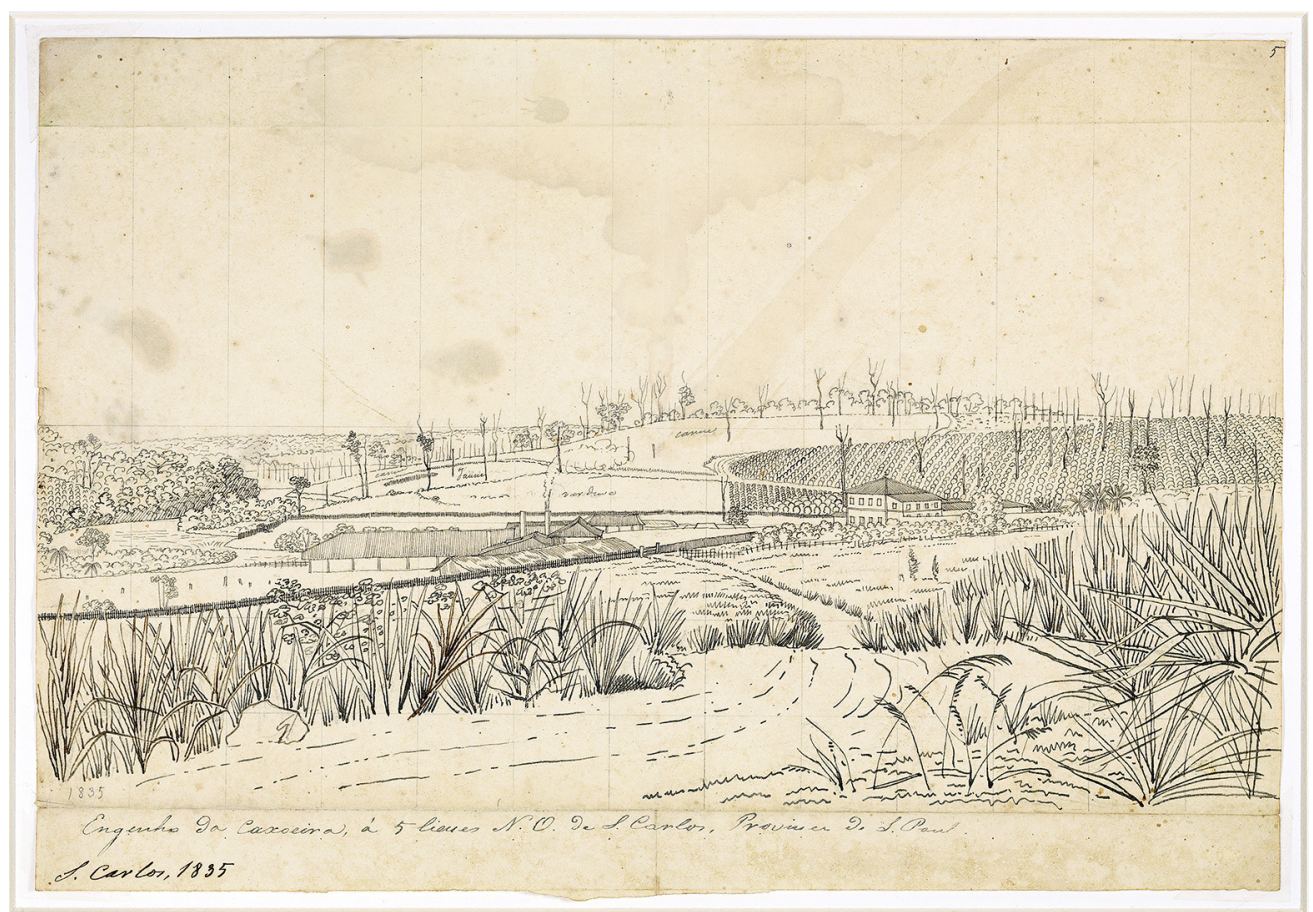

Figura 1 - Hercule Florence, Engenho da Caxoeira, a 5 léguas de S. Carlos, Província de S. Paulo, 1835, nanquim sobre papel, 25,9 × 37,7 cm. Coleção Cyrillo Hercules Florence.

Em seu diário, Florence anotou: "O sítio de Antonio Manoel Teixeira é um passeio muito agradável a cinco léguas N.O. de São Carlos, Província de S. Paulo. A bondade deste senhor é extrema"15.

Com base nesse esboço, Florence fez uma das suas aquarelas mais impressionantes. $\bigcirc$ artista foge do colorido, usa lápis e crayon e seus traços reproduzem matizes de preto e branco em tons claros e escuros, projetando sombras e luzes no chão e nos escravos. $\bigcirc$ artista intitulou a obra Partida dos negros para a roça ${ }^{16}$. Sutilmente, parece que assistimos a uma cena cinemato-
14. Ver Dirceu Franco Ferreira; Nelson Mendes Cantarino (2009); Boris Kossoy (1980); Leila Florence (2010); Hercule Florence... (2009).

15. Cf. Hercule Florence.. (2009, p.84).

16. A pintura foi nomeada no manuscrito L'Inventeur au Brésil - 7me. Envoi, por Partida de negros para a roça. Cf. Hercule Florence... (2009, p. 85) 
gráfica que o inventor da fotografia concebeu provavelmente nos anos de 1830 (Figura 2).

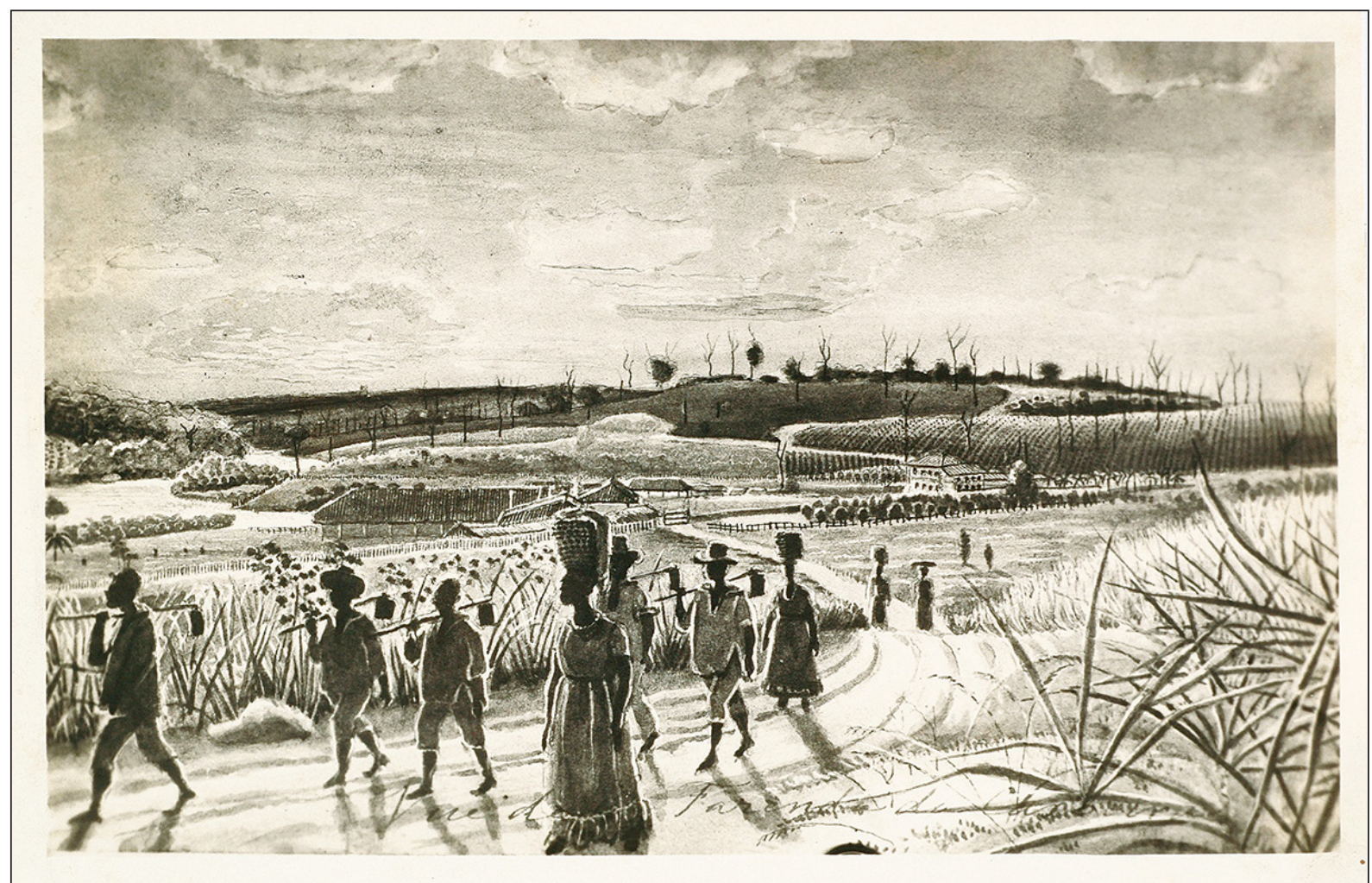

Figura 2 - Reprodução de aquarela de Hercule Florence, sem título, (Partida dos Negros para a Roça), sem data. Museu Paulista da Universidade de São Paulo.

Há outra aquarela, Vista do sítio de Antonio Manoel Teixeira, sem data (provavelmente 1835), que mostra, em primeiro plano, o proprietário e um hóspede, para, em seguida, abrir em uma vista panorâmica a propriedade margeada pelo rio Jaguari. Distinta da Partida dos negros para a roça, nela o artista explora as cores e os diversos tons do verde, amarelo, oliva, marrom, ocre, cinza, branco e minúsculas florzinhas em bordô. É delicada e, ao mesmo tempo, exuberante (Figura 3).

No detalhe da aquarela Vista do sítio de Antonio Manoel Teixeira (Figura 4) é possível observar o movimento das tropas de muares no carregamento de açúcar, da roda da moenda embaixo do telhado, da fumaça das chaminés do engenho em operação, e das águas serenas do rio Jaguari. Florence não desenhou o céu; parece que o artista preocupou-se em detalhar os milhares de elementos da paisagem que envolvia os dois homens. Observe-se a sombra sobre o lombo do cavalo! (Figura 3).

Nas águas tranquilas do Jaguari, Florence desenhou os reflexos do céu, das nuvens, das árvores, dos animais e das coisas. É isso que a aquarela Engenho 

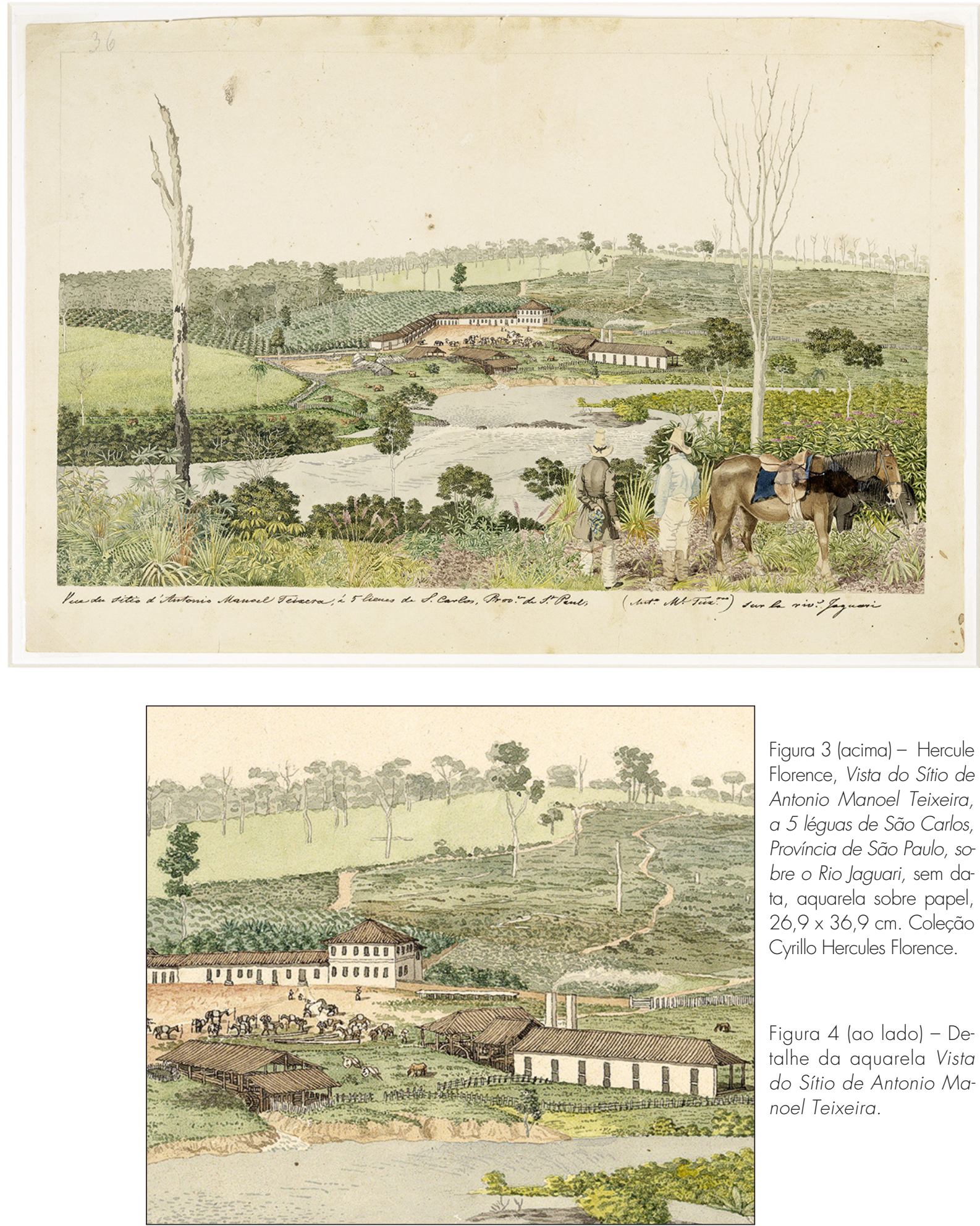

Figura 3 (acima) - Hercule Florence, Vista do Sítio de Antonio Manoel Teixeira, a 5 léguas de São Carlos, Província de São Paulo, sobre o Rio Jaguari, sem data, aquarela sobre papel, $26,9 \times 36,9$ cm. Coleção Cyrillo Hercules Florence.

Figura 4 (ao lado) - Detalhe da aquarela Vista do Sítio de Antonio Manoel Teixeira. 
17. Cf. Hercule Florence... (2009, p. 110-111); Leila Florence (2010, p. 10).

18. Cf. Hercule Florence... (2009, p. 79). da Caxoeira, Juillet 1835. Etude d'eau calme. Reflexion des objets dans une eau tranquille 17 traz ao nosso olhar (Figura 5). Ali, Florence fez um estudo dos céus em suas cores, movimentos e os formatos das nuvens. É possível observar uma sutil ondulação nas águas do Jaguari provocada pelas nuvens.

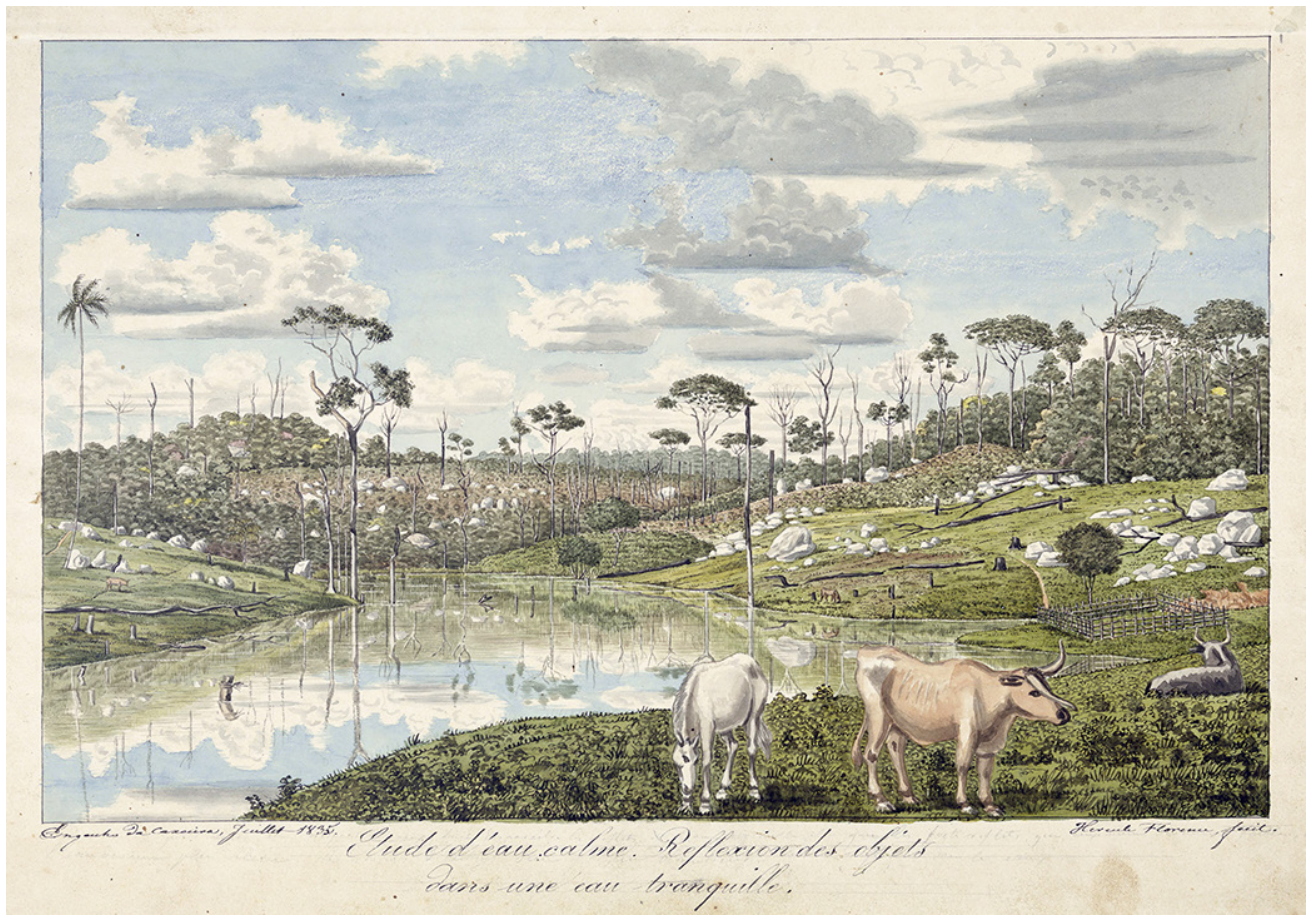

Figura 5 - Engenho da Cachoeira. Estudo de água calma. Reflexo dos objetos em água tranquila, 1835, aquarela e nanquim, 26,7 X 37,7 cm. Coleção Cyrillo Hercules Florence.

Na Moenda de açúcar movida por bois, Florence deixou a natureza e a paisagem para desenhar o movimento do trabalho no interior do engenho, onde sobressaem os movimentos circulares das duas parelhas de quatro bois cada uma, presas ao eixo central, enquanto quatro escravos dedicam-se às tarefas de colocar a cana na moenda horizontal, ordenar os feixes e retirar a cana do carretão (Figura 6).

Em 1848, a ida ao engenho da Cachoeira foi marcada pela aquarela o Engenho Caxoeira. Corte da cana de açúcar. Nela aparecem escravos em intenso movimento de colheita da cana, cada um ocupado com sua tarefa. A pintura mostra a organização do trabalho no corte da cana e ao mesmo tempo destaca a figura do feitor negro vestido com uma capa vermelha e com uma vara na mão direita, impondo a ameaça de castigo. Na anotação no seu diário, o artista escreveu:

Enquanto me encarrego de registrar com meu lápis esses quarenta negros em movimento, o Feitor negro chicoteia um negro. A mim, me parece que ele queria me mostrar seu zelo, e a ideia de que fui causa deste castigo, me faz apressar meu trabalho ${ }^{18}$. 


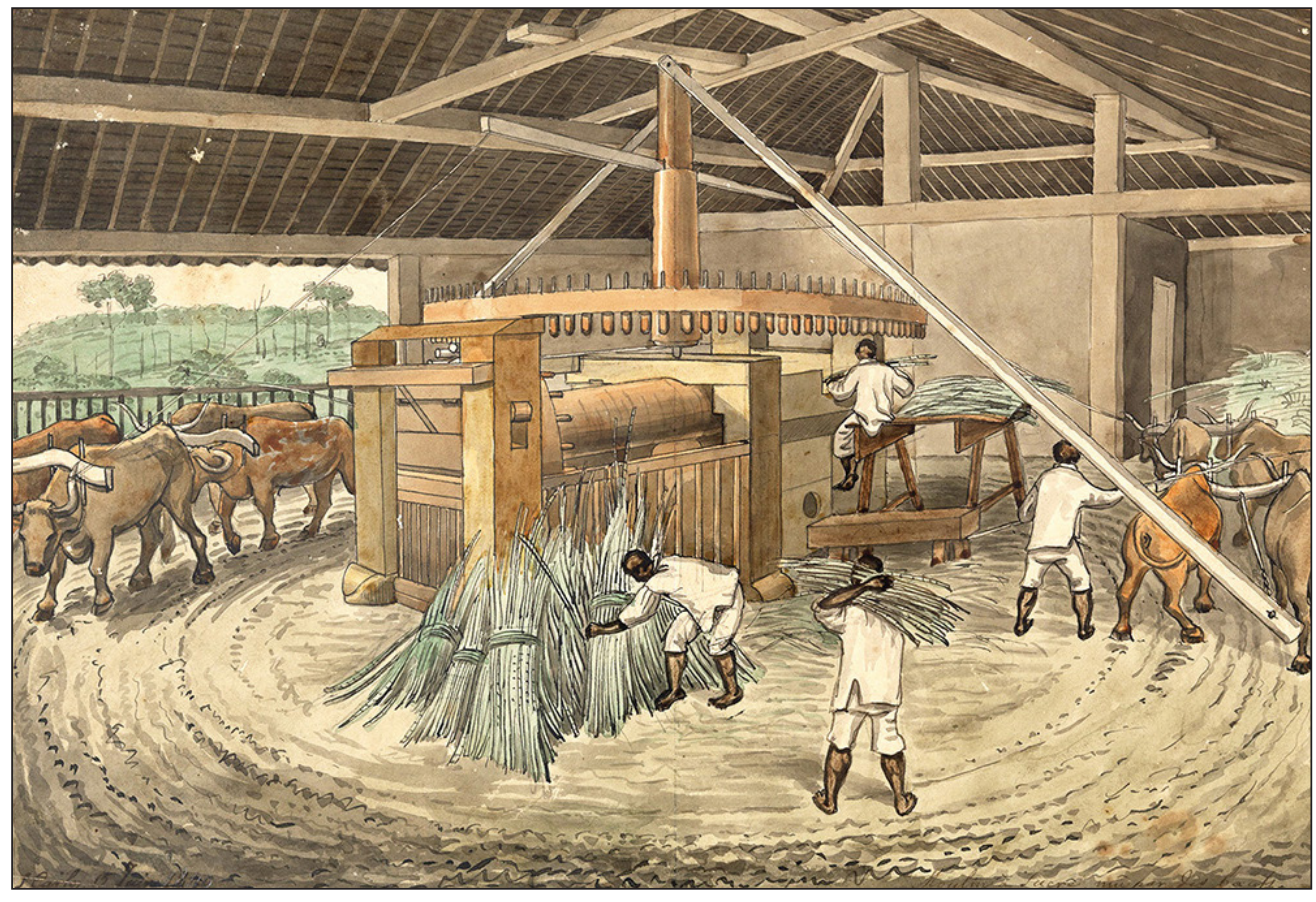

Figura 6 - Moenda de açúcar movida por bois, 1840, aquarela e nanquim sobre papel, 34,3 X 45,5 cm. Coleção Cyrillo Hércules Florence.

Restou ao artista apressar o término do desenho e, assim, ao invés de 40 escravos, registrou apenas 30. É provável que Florence tenha sido um dos únicos artistas da primeira metade do século XIX a trazer para suas obras os escravos na colheita da cana ${ }^{19}$. Na pintura, as marcas das queimadas foram deixadas nas perobeiras enormes e nos gigantescos jequitibás-rosa por manchas de um marrom forte, quase carvão. Podemos observar o desmatamento nas árvores caídas e raquíticas, evidentes exemplares da Mata Atlântica que cobriu a região do "Mato Grosso"20. É possível observar ao fundo à esquerda a plantação de café, composta por pequenos cafeeiros pouco adensados, evidenciando tratar-se de uma cultura recente. Com cores, formas e luzes, o céu e as nuvens participam da composição do horizonte (Figura 7).

A aproximação entre Antonio Manoel e Florence parece ter sido propiciada pelo sogro de Florence, o cirurgião mor Francisco Álvares Machado e Vasconcellos (1791-1846), pai de Maria Angélica Álvares Machado Florence (1812/4-1850), primeira esposa do pintor, que foi um dos testamenteiros de Antonio Manoel. Florence e Antonio Manoel tornaram-se "amigos íntimos e compadres", afirmava Amador Bueno Machado Florence (183 1-1894), filho primogênito de Florence e Maria Angélica ${ }^{21}$.

Mas não somente em suas pinturas Florence reconhecia o papel de Antonio Manoel no desenvolvimento da plantation açucareira na vila de São Carlos. Ele reconhecia o valor das iniciativas de ordem pública comandadas por
19. Para o século XVII, Frans Post registrou em suas pinturas a produção açucareira, as rodas d'águas, as rodas movidas por animais e as atividades dos escravos nos engenhos de Pernambuco. Ver Daniel Strum (2012, p. 29, 156,163).

20. O primeiro nome de Campinas, freguesia Nossa Senhora da Conceição das Campinas do Mato Grosso, fazia referência à mata adensada por grandes árvores chamadas de "mato grosso", que cobria a região.

21. Ver Maria Alice Rosa Ribeiro (2016b, p.206-211). 
22. Cf. Hercule Florence... (2009, p.99).

23. Ver Celso Maria de Mello Pupo (1969, p. 123-136); Amador Bueno Machado Florence (1882, p.1-2), em que se apoia o relato breve aqui feito. Para relembrar a Revolução Liberal, que em 1882 completava 40 anos, a Gazeta de Campinas solicitou a seu colaborador Amador Bueno Machado Florence uma série de artigos sobre o acontecimento por ele vivido quando criança. Amador Bueno descreveu o episódio em 14 crônicas publicadas entre os dias 7 de junho e 16 de julho de 1882. Sobre o episódio Ver Jolumá Brito (1952); sobre a Revolta Liberal de 1842 Ver Erik Hörner (2010).

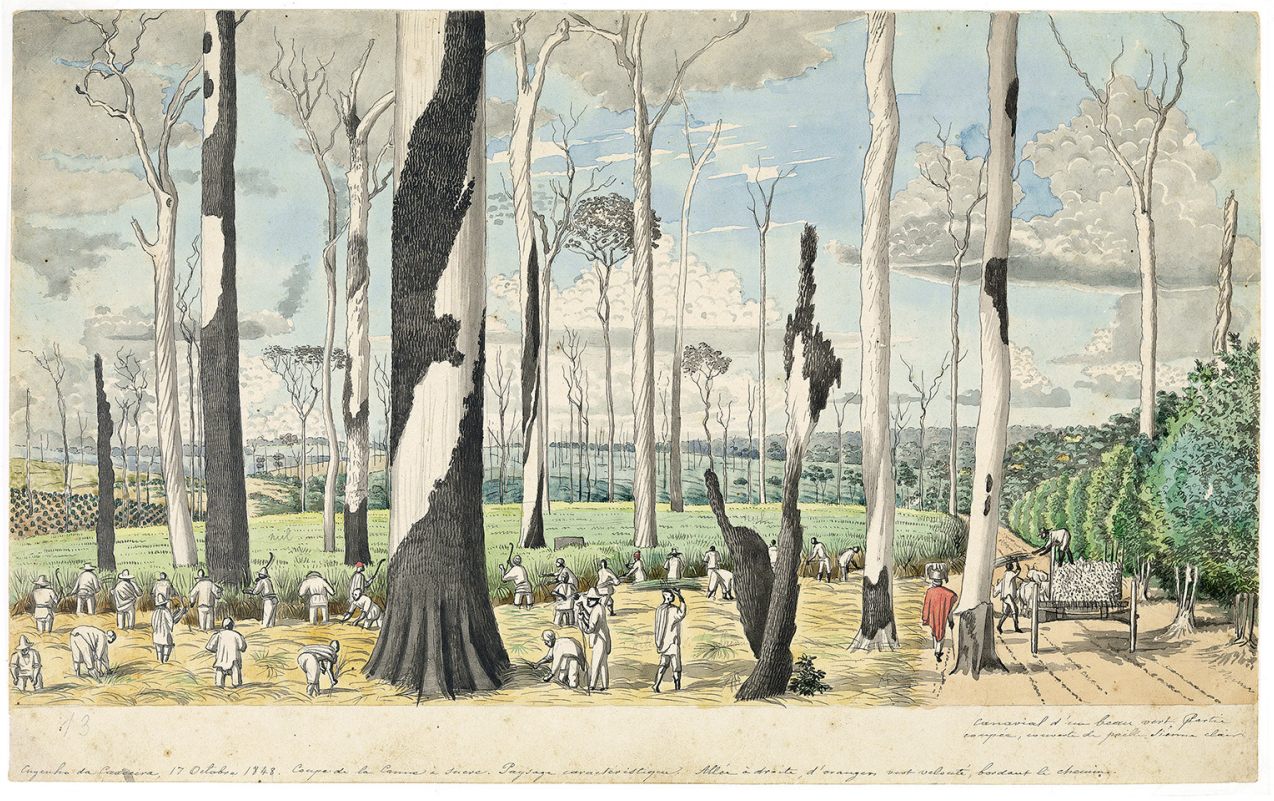

Figura 7 - Hercule Florence, Engenho da Caxoeira. Corte da cana de açúcar, 17 outubro 1848, aquarela e nanquim sobre papel, 23,4 × 37,9 cm. Coleção Cyrillo Hercules Florence.

Antonio Manoel, como as obras de construção do aterro do mangue nas margens do rio Cubatão, que melhorou o acesso ao porto de Santos e diminuiu as perdas do açúcar deteriorado pela umidade da travessia. Essa obra propiciou um avanço no transporte do açúcar e de outras mercadorias para o porto e dele para a capital e para o interior. Mas, Florence ressalta, sobretudo, o papel de Antonio Manoel na iniciativa do empreendimento, cuja obra the causou muitos prejuízos. Dizia Florence em seu diário:

Foi ele que fez a estrada de Santos a Cubatão; duas léguas e meia de aterro em um terreno lodoso e submerso. Este trabalho, de uma alta importância considerando as circunstancias topográficas do país, só poderia ser feito por ele, pois os paulistas não têm aptidão para construir estradas. O litoral da província de S. Paulo é como toda a costa Oeste da América do Sul. Os Andes fazem correr os grandes rios longes do mar que os banha: em S. Paulo, a "Serra do Mar" conduz todos eles longe do Atlântico: pode-se avaliar a importância de uma estrada para um país que retira tudo do mar, que não possui nenhum rio que deságua no mar, e que deve além disso transpor uma "Serra" cuja encosta marítima é um precipício de [em branco] metros. Antonio Manoel perdeu quarenta negros no trabalho desse trecho de estrada, devorados pelos miasmas deste terreno insalubre ${ }^{22}$.

Amador Bueno Machado Florence ressaltou os feitos de Antonio Manoel na luta política durante a Revolução Liberal de 184223, na luta contra o despotismo do governo do Partido Conservador, que dissolveu a Câmara dos Deputados em $1^{\circ}$. Maio de 1842, e contra o presidente da Província de São Paulo, José da Costa Carvalho (1796-1860), Barão de Monte Alegre. Antonio Manoel foi designado 
por Rafael Tobias de Aguiar (1794 - 1857) comandante militar, responsável pelo armamento e pela ocupação de Campinas, aliando-se na luta do ex-deputado por São Paulo às cortes de Lisboa, ex-regente e senador, padre Diogo Antonio Feijó (1784-1843), contra os conservadores. Hercule Florence juntou-se à luta e foi o editor do jornal $\bigcirc$ Paulista, impresso na sua tipografia transportada de Campinas a Sorocaba, onde se encontrava o padre Feijó, redator da folha revolucionária ${ }^{24}$. No derradeiro combate ocorrido em Campinas, um ataque surpresa das forças legalistas impôs a derrota aos revoltosos. $\bigcirc$ combate da Venda Grande, como ficou conhecido, resultou em vítimas fatais, feridos e presos. Antonio Manoel conseguiu escapar e exilou-se na Argentina. Regressou somente nos fins de 1843 com a anistia dos revoltosos.

Em 1846, na primeira visita a Campinas, Dom Pedro II reconheceu - importante papel desempenhado por Antonio Manoel no progresso de Campinas e da sociedade paulista e the concedeu o título de Comendador da Ordem da Rosa. Foi o primeiro título concedido pelo imperador a um cidadão campineiro. Entre 1846 e 1849, como comendador, Antonio Manoel Teixeira foi eleito deputado provincial nas $6^{\circ}$ e $7^{\circ}$ legislaturas ${ }^{25}$.

Antonio Manoel consolidou a plantation açucareira iniciada por seu pai e seus tios Teixeira Vilela - Teixeira Nogueira, e começou a transição do açúcar para o café, que seu filho Francisco iria consolidar, como um dos maiores cafeicultores do município, nas fazendas Santa Maria e Morro Alto.

Quando da morte de Antonio Manoel, Francisco tinha 20 anos e era considerado ainda menor. Em decorrência, o juiz de órfãos, Candido Gomide, nomeou como tutor e curador o Capitão Jaime da Silva Teles, que fora testamenteiro e inventariante de Antonio Manoel. Logo surgiram desentendimentos entre o jovem e o tutor - o primeiro acusava o tutor de estar dilapidando seu patrimônio. Os conflitos acabaram por gerar uma demanda na justiça de autoria do mesmo juiz, na qual denunciava Francisco pelo crime de desobediência ao tutor e à ordem do juiz. Ao fim e ao cabo, Francisco venceu em sua demanda de remover o tutor. Essas discussões e processos jurídicos encerraram-se por completo com a concessão de maioridade ao jovem, que passou a gerir o próprio patrimônio ${ }^{26}$.

Em 1853, dois anos após a vitória na contenda judiciária, Francisco casou-se com Maria Josefa da Conceição. $\bigcirc$ registro de casamento expunha a condição de Francisco ser filho de mãe incógnita ${ }^{27}$. Nos escritos contemporâneos não há qualquer referência a Francisco ser filho de escrava como aventou Dr. Ricardo Gumbleton Daunt que acusava Antonio Manoel Teixeira de "ter filho escravo" 28. Segundo Pupo, a afirmação é inexata, pois Antonio Manoel reconheceu o filho, batizando-o na capela do engenho Cachoeira ${ }^{29}$.

Ao longo de sua curta existência, Francisco, herdeiro universal de seu pai, aumentou a riqueza herdada em bens e propriedades, fundamentalmente, em terras e em escravos. Comprou mais terras e muitos escravos. Ampliou o cultivo no café, que seu pai apenas iniciara. As principais
24. Freitas Nobre, no seu livro História da Imprensa de S. Paulo, considera $O$ Paulista como o primeiro jornal do interior da província de São Paulo. Ver Jolumá Brito (1958, p. 40).

25. Disponível em: http:// www.al.sp.gov.br/web/ acervo2/base_de_dados/ i m p e r i o / m p e r i o deputadoshtml. Acesso em: 07 abr. 2015.

26. Autos crime de desobediência a ordem do Juiz de Órfãos. Proc. 2872, $1^{\circ}$. Of. 1851 , p.10-16.

27. Livro 5 - Casamentos Maio de 1841 a Junho de 1861 - fls. 82 verso. Disponível em: <http:// familysearch.org.>. Acesso em: 29 mar. 2015.

28. Em carta enviada ao Conselheiro do Império, José Martins da Cruz Jobim, em 18 de julho de 1850, Dr. Ricardo informava que Antonio Manoel falecera, havia três dias, "subitamente sem confissão, Absolvição da hora da Morte ou Uncção!!!". Na mesma missiva, denunciou ao conselheiro que Antonio Manoel deixou por herdeiro um filho "q elle teve com umas das suas próprias Negras! E q foi criado como cativo". Cf. Anuário do Museu Imperial (1953, p. 25-26). Agradecemos ao Dr. Heitor Ulson pela indicação da carta. Dr. Ricardo tinha uma língua ferina, pois Francisco não foi criado como cativo, com atestavam o registro de batizado e o testamento de seu pai Antonio Manoel Teixeira.

29. Cf. Celso Maria de Mello Pupo (1969, p. 240). No registro de batismo de Francisco Teixeira Vilela constava apenas o nome do batizado e, na filiação - filho natural, o nome do pai, Antonio Manoel Teixeira; o nome da mãe estava em branco. Disponível em: http://www.familysearchorg/ pal: Livro 4, fls.131 verso. Acesso em: 24 jan. 2013. 
30. No ano de 1873 , o número de escravos arrolados no inventário de Francisco era de 457 , segundo a relação de matrícula realizada pelo comendador em setembro de 1872. O comendador matriculou seus escravos seguindo a legislação de 1871 . A relação recebeu o número 832, nota de assentamento de matricula em 03 de setembro de 1872. Proc. 4359, 1873, p. 25 , v. a 65 e 73 a 86.

31. Dinheiro a prêmio é a forma que se designava empréstimos de dinheiro a juros. No século XIX, eram chamados de capitalistas aqueles que emprestavam dinheiro a prêmio ou a juros.

32. Ver Eduardo Spiller Pena (1999); Octavio Ianni (1985).

33. Ver Maria Alice Rosa Ribeiro (2015, p.551-553).

34. Ver Maria Luísa de Freitas Duarte Páteo (1997).

35. Disponível em: http:// www.fsantamaria.com.br/ historia.htm. Acesso em: 22 mai. 2010. propriedades de Francisco e de sua esposa, as fazendas Santa Maria e Morro Alto possuíam um milhão de pés de café e mais de 400 escravos ${ }^{30}$. Entretanto, o ritmo frenético da expansão dos seus negócios somente foi possível com a obtenção de empréstimos no mercado de dinheiro a prêmio ${ }^{31}$. Crescia cada vez mais sua dívida junto a terceiros. Um exemplo marcante de endividamento foi a compra de 186 escravos vindos de Castro, Paraná, em 186832. Francisco tomou um crédito hipotecário junto à casa comissária Teixeira Leite e Sobrinhos, do Rio de Janeiro, e a outros capitalistas, aos quais hipotecou as fazendas e os escravos ${ }^{33}$.

Os escravos vindos de Castro pertenciam à fazenda Capão Alto, de propriedade da ordem religiosa Carmelita, arrendada à firma Gavião, Ribeiro \& Gavião, de São Paulo, que os vendeu a Francisco Teixeira Vilela. Vindos de uma instituição religiosa, é provável que alguns cativos tivessem cultura musical e familiaridade com instrumentos musicais, o que serviu de incentivo para que o Francisco organizasse a banda da fazenda Santa Maria. Uma notícia no Almanak de Campinas para 1873, sob o título "Musica de pretos", conta que o comendador organizou uma banda "em sua notável fazenda Santa Maria" (Figura 8); a única banda formada por escravos de uma fazenda em Campinas ${ }^{34}$. Infelizmente há apenas essa referência à banda.

\section{Musiea de pretos}

0 sr. commendador Francisco Teixeira Vilella levou a effeito, em sua notavel fazenda de "Santa Maria), a organisação de uma banda de musica toda ella composta de escravos seus. Por duas vezes tem ella vindo á cidade, captando sempre immenso interesse já pela sua originalidade, já pelos progressos alcançados em um tempo muito curto, pois executam com saliente pericia e muita justeza pecas lindas e difficeis. Muitos rapazes revellam mesmo aptidões excepcionaes para a arte e assim chamam sobre si 0 applauso sineero.

Pela inauguracão da estrada de ferro, esta banda andou em passeiata muitas vezes pelas ruas e sempre foi um alvo de todas as vistas, dando mostra, ainda por outro lado, do bom gos. to do sr. commendador Vilella.

0 respectivo mestre é o talentoso professor sr. Sabino Antonio da Silva, a cuja proficiencia é devido por certo todo 0 adiantamento dos discipulos.

Figura 8 - Nota sobre a banda de musica de pretos da fazenda Santa Maria. Almanack de Campinas (1873, p.46).

Como já mencionado, na inauguração da estação da Cia Paulista de Estradas de Ferro, a banda da Fazenda Santa Maria executou a peça musical A estrada de ferro ${ }^{35}$.

Francisco apreciava música e mantinha relações de amizade com músicos da cidade e de fora. Para ensinar e ensaiar a banda de escravos da Fazenda Santa Maria foi contratado o maestro, compositor e professor Sabino 
Antonio da Silva, que teria vindo do Rio de Janeiro e morado na própria fazenda por três anos (1869-1873) 36 .

A amizade entre a família Teixeira Vilela e a família Gomes poderia ter suas raízes nos tempos da chegada de Manoel José Gomes à Vila de São Carlos por volta de 181537, onde foi atuar como mestre-de-capela, pessoa responsável pela música nas igrejas. Nas listas nominativas de 1817 e 1818 , constava na primeira Companhia de Ordenanças, o nome de Manoel José Gomes, natural de Parnaíba, 26 anos, pardo, músico, casado; mas não constava o nome da esposa. Não possuía escravos, mas um agregado, Antonio, de $6 \operatorname{anos}^{38}$. As atividades de mestre de capela na matriz velha devem ter aproximado Manoel José Gomes (ou Maneco Músico) da família Teixeira Vilela - Teixeira Nogueira, que era atuante na vida religiosa de Campinas. Desde adolescente, Carlos Gomes (ou Tonico) ajudava o pai nos serviços musicais da igreja, sendo considerado por Maneco Músico, imprescindível ${ }^{39}$. Isso teria facilitado a aproximação entre Francisco, Carlos Gomes ${ }^{40}$ e irmão deste Sant'Anna Gomes ${ }^{41}$.

Até a década de 1870, a presença do piano nas casas da elite era um fato raro e poucas famílias tinham instrumentos musicais. No inventário de Antonio Manoel, de 1850, constava um piano no engenho da Cachoeira, avaliado em $400 \$ 000$ (quatrocentos mil réis) ${ }^{42}$. Francisco herdou o piano, que continuou na família após sua morte. Infelizmente, não encontramos no inventário, o assentamento dos instrumentos da banda de música formada pelos escravos da Santa Maria.

Francisco Teixeira Vilela faleceu em 17 de outubro de 1873, com a idade de 44 anos. Já na abertura do inventário, em 28 de outubro de 1873, afirmou-se que o comendador "morreu repentinamente e sem testamento". Os louvados (avaliadores), o advogado e os curadores constataram que as dívidas passivas, os créditos hipotecários e comercias, eram superiores ao acervo patrimonial $^{43}$. Apesar de amealhar uma enorme riqueza, Francisco gerara uma dívida que se mostrava impagável. O principal credor, o Banco Rural e Hipotecário do Rio de Janeiro, assumiu a gestão do acervo, levando as propriedades Santa Maria, Morro Alto e outras à venda para quitar as dívidas. $\bigcirc$ falecimento prematuro do comendador pegou-o completamente endividado: faltou-the o tempo necessário para recuperar suas finanças e preservar suas propriedades.

Carlos Gomes e a composição da quadrilha - Caxoeira, Santa Maria, Morro Alto, Saltinho e Mogy Guassú

compositor Carlos Gomes ${ }^{44}$ permaneceu em Campinas até 1859, quando, após um período em São Paulo, partiu para Rio de Janeiro, matriculandose no Imperial Conservatório de Música. Em 1863, por ter sido o aluno mais destacado da escola, recebeu uma bolsa de estudos e embarcou em seguida
36. Ver Lenita Waldige Mendes Nogueira (2001, p. 403-404).

37. Ver Lenita Waldige Mendes Nogueira (2001, p.319-320). Maneco Músico, como ficou conhecido chegou a Campinas por volta de 1815 .

38. Cf. Maços de População (1817, p. 21 ; 1818, p.27).

39. Ver Lenita Waldige Mendes Nogueira (2001, p. 322).

40. Carlos Gomes (Campinas, 1836 - Belém do Pará, 1896) foi, no campo da ópera, o compositor brasileiro mais destacado no século XIX. Viveu grande parte de sua vida em Milão, onde estreou diversos trabalhos, com destaque para Il Guarany, apresentado em 1870, no Teatro alla Scala de Milão.

41. José Pedro de Sant'Anna Gomes (Campinas, 18341908), irmão de Carlos Gomes, foi compositor, regente e empresário musical. Viveu toda a sua vida em Campinas e sua obra está preservada no Museu Carlos Gomes em Campinas, assim como as cópias de arranjos que fez de obras do irmão. Ver Lenita Waldige Mendes Nogueira (1997, p. 321-348).

42. Cf. Proc. n. 2899, 1852 , p. $131 \mathrm{v}$.

43. No transcorrer das primeiras declarações, as dívidas passivas foram estimadas em Rs 1.400:000\$000 (um mil e quatrocentos contos de réis), e o patrimônio que calculamos com base no inventário atingiu o valor de 1.247:769\$880 (um mil duzentos e quarenta e sete contos, setecentos e sessenta e nove mil e oitocentos e oitenta réis). Ver Maria Alice Rosa Ribeiro (2015, p. 554).

44. Em 2016, temos duas datas importantes relativas a Carlos Gomes: 180 anos de nascimento e 120 anos de morte. 
45. Segundo a notícia do jornal, no retrato Florence utiliza de técnica mista desenho a lápis ou crayon e aquarela sobre o papel. A obra foi doada ao Museu do Centro de Integração de Empresa e Escola, CIEE, de São Paulo, em 2011, pelo casal Jayme de Ulhôa Cintra e Toledo Piza e Maria de Fátima Gonçalves Rocco. Cf. Correio Popular (2015, Caderno C, p. B7). para a Itália, onde passou a viver, retornando ao Brasil apenas eventualmente. Foi contemporâneo tanto de Francisco Teixeira Vilela como de Hercules Florence, que chegou a Campinas, ainda Vila de São Carlos, em 1829.

Na bibliografia disponível ainda não há estudos aprofundados sobre a relação desses dois artistas. Recentemente, veio a público uma obra até então desconhecida assinada por Hercule Florence, datada de 1866, que retrata Carlos Gomes com, aproximadamente, 30 anos de idade 45 (Figura 9).

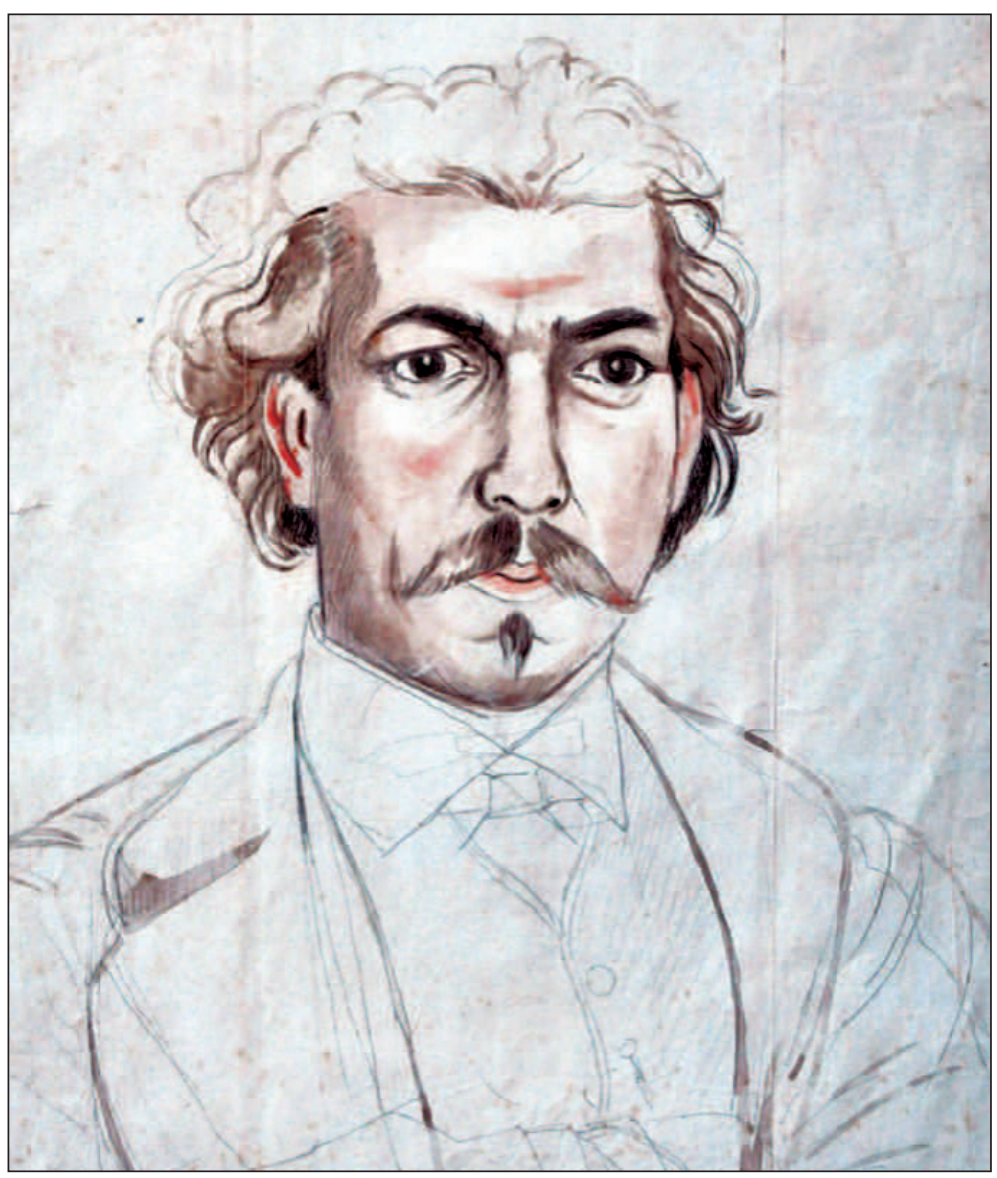

Figura 9 - Retrato de Carlos Gomes, de autoria de Hercule Florence, em 1866. Correio Popular (2015 p. B7).

As pinturas de Florence do engenho Cachoeira foram feitas entre 1835 e 1848, um pouco antes do nascimento até a infância de Carlos Gomes. Seria inapropriado afirmar que ele teve a oportunidade de conhecer as aquarelas ou que elas serviram de inspiração para sua Caxoeira-Quadriglia para piano, composta quando o maestro já vivia em Milão. A peça foi publicada pela Casa Editora Lucca de Milão e traz as seguintes informações na capa:

Caxoeira - Quadriglia / per / Pianoforte / Espressamente composta e Dedicata / Al suo Amico / F. Teixeira Vilella / (di Campinas) / Da A. Carlos Gomes / Milano F. Lucca 
Na capa dessa partitura impressa encontramos o preço - Fr. 2,25 - e o número da chapa da editora Lucca - 16579, mas não há qualquer registro da data de publicação. Teoricamente, com o número da chapa seria possível localizar o original, mas isso é absolutamente improvável, já que a Casa Lucca foi absorvida pela Editora Ricordi, também de Milão, que, por sua vez, sofreu grandes bombardeios na $2^{a}$ Grande Guerra, perdendo parte importante de seus originais (Figura 10).
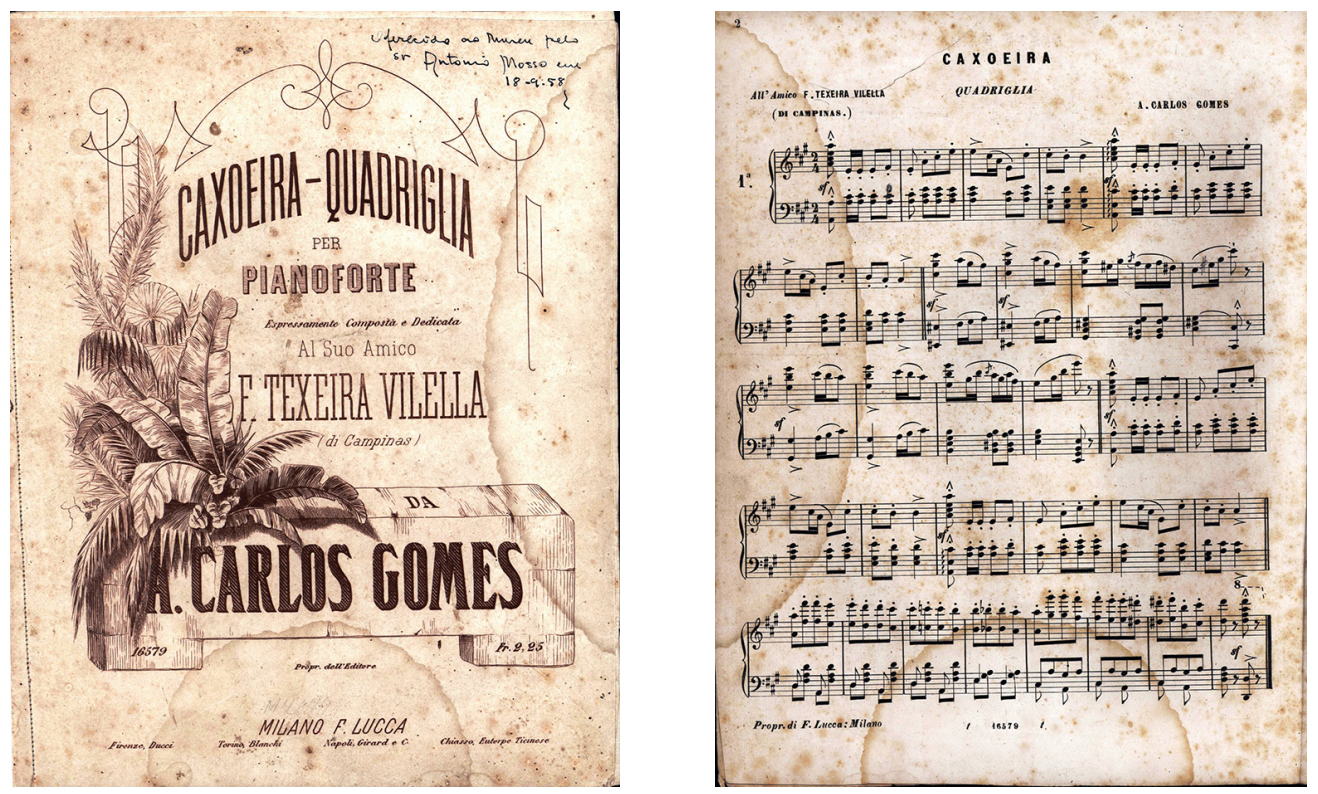

Figura 10 - Capa e primeira página da edição italiana da Caxoeira-Quadriglia. Museu Carlos Gomes

A mesma composição foi publicada posteriormente no Rio de Janeiro pelo editor Domenico Filippone, em uma coletânea chamada "Ramalhete de Quadrilhas de contradanças". Não temos elementos para avaliar se a impressão utilizou a mesma chapa da Casa Lucca. Embora também não traga a data, há algumas inscrições à mão na capa, com a data de 1883, o que indica que essa publicação deve ser posterior à edição italiana (Figura 111).

A data da composição, 1867, nos chegou por outros caminhos: um arranjo para orquestra que Sant'Anna Gomes fez dessa composição (Figura 12). Na primeira página está estampado:

Caxoeira Quadritha / para orchestra composta e dedicada / Ao seu amigo Com dor / Fran ${ }^{c o}$ Teixeira Vilella por / Antonio Carlos Gomes (Milano 20 de [ileg.] de 1867) / Arranjado pa. orchestra p Sant'Anna Gomes / Campinas 2 de $10^{\text {bro }}$ de $1867^{46}$.

Esse documento nos esclarece, portanto, que a composição data de 1867, quando Carlos Gomes já estava definitivamente em Milão. Apesar da
46. Cf. José Sant'Anna Gomes (1867); Carlos Gomes (s/d [1867]). Interessante destacar a relação de Gomes com a Casa Lucca, primeira a publicar Caxoeira-Quadriglia, cerca de três anos antes da tão criticada venda dos direitos de Il Guarany para a editora. Quando estreou $I l$ Guarany, em 1870, Gomes foi imediatamente assediado por essa editora para vender os direitos de publicação da obra. Alguns autores afirmam que o "modesto caipira de Campinas" teria vendido por preço muito baixo e perdido os direitos futuros sobre a ópera. 


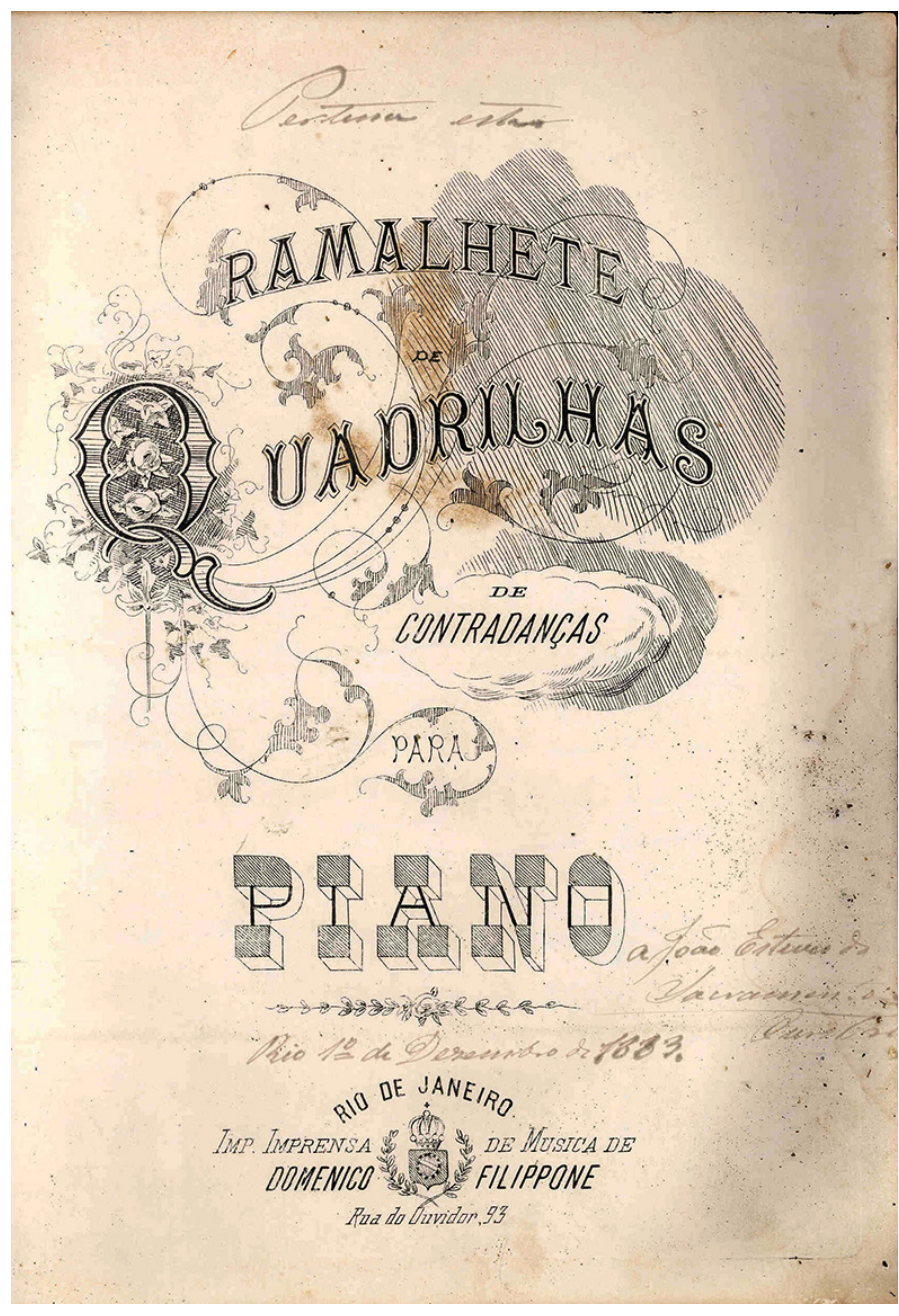

Figura 11 - Ramalhete de Quadrilhas de Contradanças para Piano. Museu da Inconfidência - Coleção Anália Esteves Ribas.

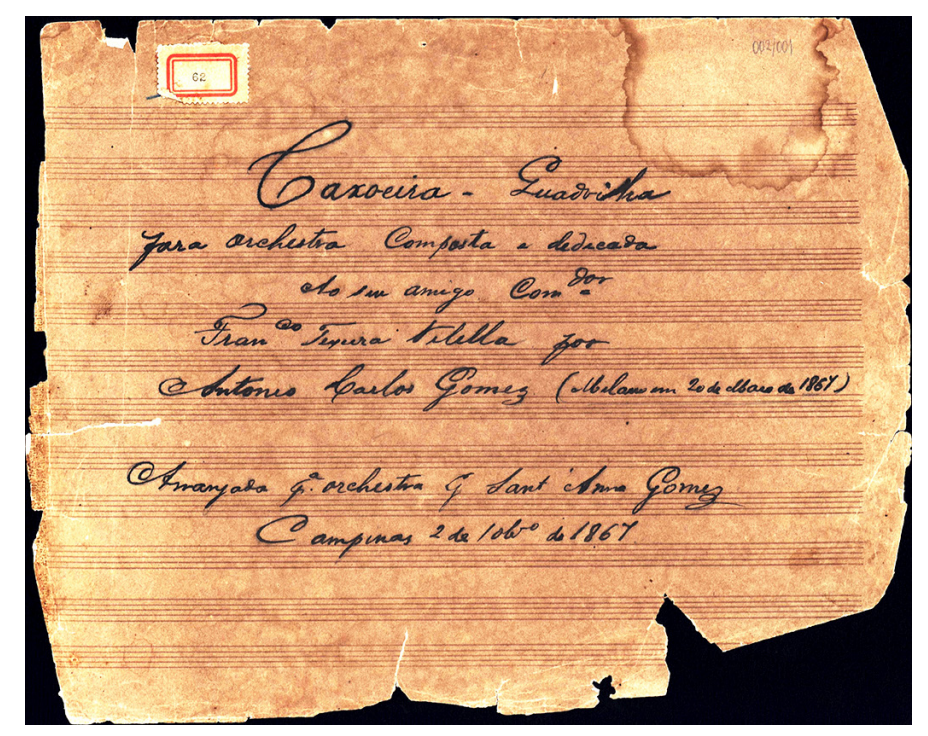

Figura 12 - Detalhe da primeira página da partitura manuscrita do arranjo feito por Sant'Anna Gomes 1867. Museu Carlos Gomes. 
distância geográfica, essa quadriglia, fiel aos padrões dessa forma musical, é formada por cinco contradanças, sendo quatro delas relacionadas às fazendas da família Teixeira Vilela: Caxoeira, Santa Maria, Morro Alto e Saltinho. A quinta contradança é exceção, pois Mogy-Guassú provavelmente remete ao rio homônimo e/ou à povoação atravessada por ele - atual cidade de Mogi Guaçu, distante cerca de 70 quilômetros de Campinas.

A quadrille surgiu na França, no século XVIII, e se tornou uma das danças mais populares nos salões século XIX. Consiste de um elaborado conjunto de passos e em geral dançada por quatro, seis ou oito casais ${ }^{47}$.

Esta manifestação teve grande aceitação nos salões de baile no Brasil oitocentista, especialmente a partir de 1820. Dançada em geral por quatro pares, consistia em cinco (eventualmente seis) contradanças, cada uma com uma determinada combinação de figuras. Para nomear as partes foram mantidas as primeiras palavras de contradanças antigas. A primeira delas é Le Pantalon, geralmente em $6 / 8$, por vezes $2 / 4$; na sequência temos L'Été, em 2/4, que é sempre mais lenta que a anterior; La Poule, em 6/8, mais agitada que a anterior e de melodia ondulada; La Pastourelle (eventualmente podem aparecer outra contradança La Trénis; nesse caso, a quadrilha teria seis peças), 2/4, bem mais vivo que La Poule; a última é Le Finale, cuja estrutura deve permitir apressar o andamento, sem provocar correria dos dançarinos. A música da quadrilha é bastante animada e todos os trechos têm a extensão fixa de oito ou dezesseis compassos.

Diversos compositores europeus dedicaram-se ao gênero, sendo os mais famosos os vienenses Johann Strauss e Johann Strauss Filho, mas também era frequente a composição de quadrilhas sobre temas de óperas ou de peças bastante conhecidas. Por seu ritmo animado, se prestava bastante a paródias e chacotas.

No Brasil, o gênero acabou se mesclando com as tradições populares, gerando a quadrilha caipira, típica das festas juninas, na qual ainda se pode notar a origem francesa que aparece em termos como "balancê, traversê, changê, anarriê", entre outros.

Ao escrever esse conjunto de cinco peças que chamou de CaxoeiraQuadriglia, Carlos Gomes trabalhou exatamente dentro dessa estrutura, mantendo, inclusive, a ordem estabelecida pela tradição. A primeira contradança, Caxoeira, corresponde a Le Pantalon. De ritmo vivaz, está escrita em Lá Maior e compasso 2/4, e nota-se a presença de muitas notas em staccato, o que dá uma configuração alegre e saltitante. Como vimos acima, a segunda contradança é sempre mais lenta que a anterior, e assim é Santa Maria, que corresponde a L'Été. Embora tenha a mesma forma e a mesma métrica musical da Le Pantalon, seu caráter se aproxima do melancólico, o que já é indicado pela tonalidade, Si Menor. Sendo a única do conjunto com essa característica, Santa Maria começa misteriosa, uma oitava seguida por staccatos e apogiaturas com a indicação de piano, ou seja, deve ser tocada com pouco volume. A segunda parte é um pouco mais movimentada, mas ainda não chega a empolgar ritmicamente.
47. Ver Andrew Lamb (2001 p. 652-654). 
48. O jornal Diário da Noite, edição de 13 de julho de 1936, afirma que Joaquina Gomes deu uma entrevista à Hora do Brasil, no dia 11 de julho de 1836, durante as comemorações pelo centenário do compositor.
Como La Poule aparece Morro Alto. Em Ré Maior com ritmo 6/8, a animação é garantida, retomando o espírito de Caxoeira. A segunda parte, em Si Menor, tenta, mas não consegue fugir à animação.

A quarta contradança é Saltinho e na quadrilha esse é o momento de La Pastourelle. E é exatamente o clima pastoral que Gomes apresenta aqui. Escrita na tonalidade leve de Sol Maior, retoma o compasso 2/4, e embora na escrita também se destaquem muitos staccatos, seu clima mais delicado sugere pastores e ovelhas, elementos que certamente não compunham a paisagem do engenho Saltinho.

Gomes intitulou essas quatro contradanças com nomes de propriedades da família Teixeira Vilela, mas como tinha que completar a forma, acrescentou Mogy Guassú, como Le Finale, quinta peça da quadrilha (áudio).

Com a composição dessas peças dedicadas "Ao amigo F. Teixeira Vilela (di Campinas)", Carlos Gomes devia ter em mente alguns aspectos daquelas propriedades que tentou descrever. Possivelmente até a escolha do gênero quadrilha e a ordem das peças tenham sido influenciadas pelas impressões que tinha daqueles locais. Qual o contato de Gomes com essas fazendas é uma passagem que podemos apenas inferir. Em relação a isso, sabe-se, por meio do depoimento da irmã de Gomes, Joaquina ${ }^{48}$, que o maestro, por volta de 1850, começou a dar aulas de música nas fazendas da região. Teria sido então professor da família de Francisco Teixeira Vilela? Como dito anteriormente, havia uma orquestra de escravos na Fazenda Santa Maria, dirigida por Sabino Antonio da Silva, mas, ao que tudo indica, foi criada em época posterior, entre 1869 e 1873, quando Gomes já vivia na ltália.

Em 1870, para a estreia de II Guarany em Milão, Sant'Anna Gomes arrecadou em Campinas uma grande soma de dinheiro para custear as despesas e os pagamentos da montagem da ópera no Teatro alla Scala, que cedeu apenas os cantores e a orquestra. Entre os que contribuíram, certamente, estaria Francisco Teixeira Vilela, então o maior cafeicultor da região de Campinas, a quem, cerca de três anos antes, Gomes dedicara a sua Quadrilha Caxoeira.

Duas cartas originais de Carlos Gomes, pertencentes ao acervo do Museu Carlos Gomes, em Campinas, indicam que, em data bastante posterior, o compositor ainda mantinha um relacionamento com a família Teixeira Vilela. As cartas, dirigidas a "Teixeirinha Vilella", que acreditamos se tratar de José, filho de Francisco (Campinas, 1854 - Pirassununga ou Porto Ferreira, 1900), têm um tom cordial e indicam uma relação de proximidade. Em uma das cartas, inclusive, Gomes chama o outro de "Primo Teixeirinha", provavelmente apenas uma relação carinhosa, não de parentesco (Figura 13).

que se pode concluir é que Gomes e Francisco Teixeira Vilela nasceram com poucos anos de diferença um do outro. $\bigcirc$ primeiro, em cartas escritas no fim de sua vida, lembra sua infância com alegria. Já o segundo, filho natural de pai que o reconheceu como filho único e herdeiro universal e de mãe desconhecida, foi criado numa família religiosa e grande proprietária de escravos 
e terras e, por alguns anos, teve sérios problemas com o tutor que the foi designado após a morte do pai. Certamente se conheceram, o que não se pode afirmar é o grau de amizade entre eles, mas talvez a composição da Caxoeira-Quadriglia indique uma relação mais próxima.

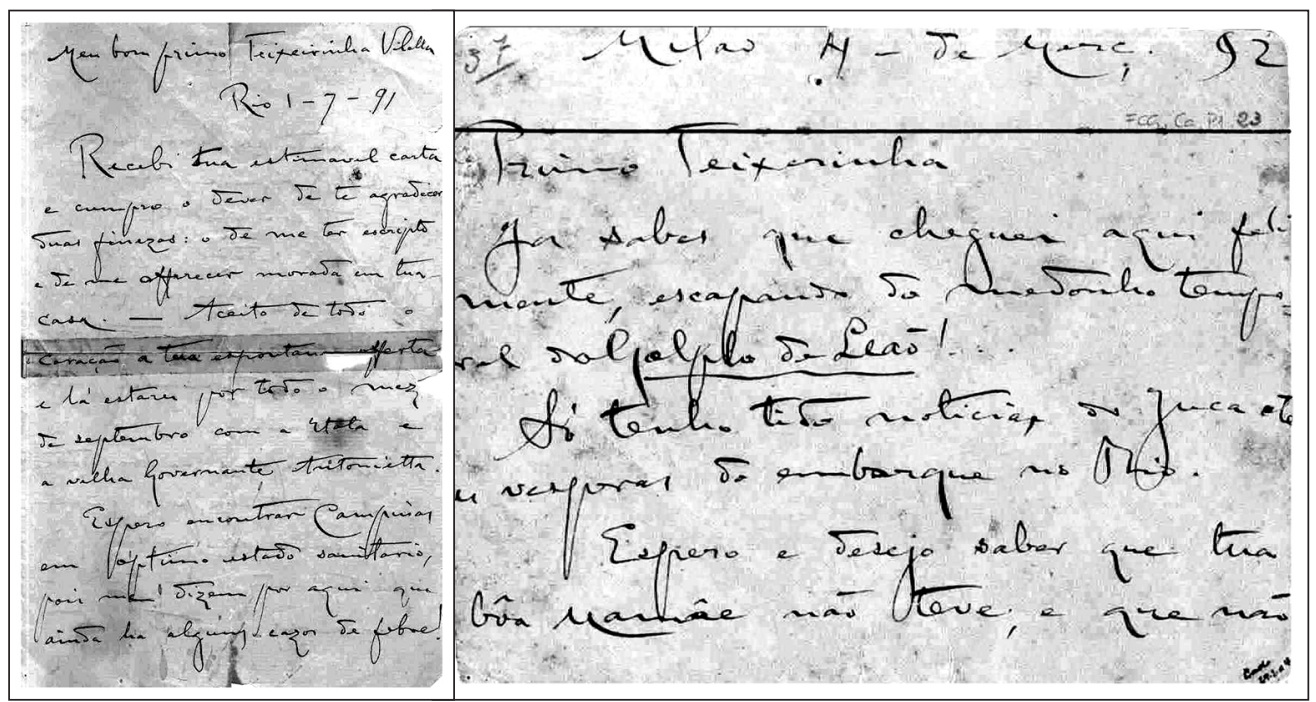

Figura 13 - Cartas de Carlos Gomes para Teixeira Vilella, Rio, 1-7-1891 e Milão, 4 de março 1892. Museu Carlos Gomes.

Quando Francisco faleceu repentinamente, em 1873, Carlos Gomes vivia seu esplendor na ltália e já havia apresentado no prestigioso Teatro alla Scala de Milão duas óperas, II Guarany (1870) e Fosca (1873). 


\section{REFERÊNCIAS}

\section{FONTES}

Anuário do Museu Imperial. Petrópolis, Ministério da Educação e Saúde, vol. 14, 1953.

Autos crime de desobediência a ordem do Juiz de Órfãos. Proc. 2872, $1^{\circ}$. Of. 1851. Centro de Memória Unicamp (CMU).

Almanak de Campinas para 1873. Organizado e publicado por José Maria Lisboa. Typografia da Gazeta de Campinas, Campinas, 1872. Centro de Memória Unicamp (CMU).

Correio Popular, Campinas, 25 de setembro, 2014, p. C1.

Correio Popular, Campinas, 06 de setembro de 2015, Caderno C, p B7.

Diário da Noite. São Paulo, 13 de julho de 1936.

GOMES, Carlos. Cartas. Campinas, Museu Carlos Gomes.

Caxoeira Quadriglia per pianoforte. Milano: F. Lucca, [18-?]. Campinas, Museu Carlos Gomes. Partitura.

Caxoeira-Quadrilha. In: Ramalhete de Quadrilhas de contradanças. Rio de Janeiro: Imp. Imprensa de Música de Domenico Filippone, s.d. Museu da Inconfidência. Setor de Musicologia. Ouro Preto, MG. Partitura.

Caxoeira - Quadrilha para orchestra. Arranjo para orquestra de Sant'Anna Gomes. Campinas, 1867. Museu Carlos Gomes. Partitura manuscrita.

Deputados Provinciais. Disponível em: <http://www.al.sp.gov.br/web/acervo2/base_de_ dados/imperio/imperio.deputadoshtml.> Acesso em: 07 abr. 2015.

Fazenda Santa Maria. Distrito de Joaquim Egydio, Campinas. Disponível em http://www. fsantamaria.com.br/historia.htm.. Acesso em: 22 mai. 2010.

Inventário do Comendador Francisco Teixeira Vilella. Proc. n. 4359, $1^{\circ}$. Of., 1873. Centro de Memória Unicamp (CMU).

Inventário e Testamento de Antonio Manoel Teixeira. Proc. 2899, 1º. Of., 1850. Centro de Memória Unicamp (CMU). 
Livro 4 - Batismo - Francisco Teixeira Vilella. Disponível em: http://www.familysearchorg/ pal. Acesso em: 24 jan. 2013.

Livro 5 - Casamentos - Maio de 1841 a Junho de 1861 - fls. 82 verso. Disponível em: http:// familysearch.org. Acesso em: 29 mar. 2015.

Maços de População de São Paulo (MP). Disponível em: http://www.arquivoestado.sp.gov.br/ viver/recenseando.php. Acesso em: 11 mar. 2013.

O piano 'brazileiro' de Carlos Gomes. Intérprete Fernando Lopes. Rio de Janeiro, Funarte, 1981. Relançamento em CD pelo Instituto Itaú Cultural. Ministério da Cultura, Funarte, São Paulo, [1995-2002].

\section{REFERÊNCIAS BIBLIOGRÁFICAS}

BRITO, Jolumá. Combate da Venda Grande (Episódios da Revolução de 1842) Campinas, [s.n.],1952.

História da cidade de Campinas. Campinas, [s.n.] v. 61958.

EISENBERG, Peter L. Homens esquecidos. Escravos e trabalhadores livres no Brasil nos séculos XVIII e XIX. Campinas: Editora da Unicamp, 1989.

FERREIRA, Dirceu Franco; CANTARINO, Nelson Mendes. Um humanista nos trópicos: a singular trajetória de Hercule Florence no Brasil. In: VIDAL, Laurent; LUCA, Tania Regina de (org.). Franceses no Brasil. Séculos XIX-XX. São Paulo: Editora UNESP, 2009, p. 397-420.

FLORENCE, Leila (org.) Céus: o Teatro Pitoresco-Celeste de Hercule Florence. São Paulo: Florescer Produções Culturais, 2010.

Hercule Florence e o Brasil: percurso de um artista inventor. Apresentação de Marcelo Marcos Araújo. Curadoria e texto de Leila Florence. Textos de Carlos Martins e Valéria Picolli. São Paulo: Pinacoteca do Estado, 2009.

HÖRNER, Erik. Em defesa da Constituição. A guerra entre rebeldes e governistas (1838-1844). Tese (Doutorado em História Social). Faculdade de Filosofia, Letras e Ciências Humanas FFLCH, São Paulo, 2010.

IANNI, Octavio. Metamorfoses do escravo. Apogeu e crise da escravatura no Brasil meridional. 2. ed. São Paulo: Hucitec, 1985. 
KOSSOY, Boris. Hercules Florence: 1833, a descoberta isolada da fotografia no Brasil. São Paulo: Duas Cidades, 1980.

LAMB, Andrew. Quadrille. In: The New Grove Dictionary of Music and Musicians. Londres: Oxford Press, v. 20, 2001. p. .652-654.

LAPA, José Roberto do Amaral. Os cantos e os antros. Campinas 1850-1900. São Paulo: Editora da Universidade de São Paulo, 1996.

MARTINS, Valter. Nem senhores, nem escravos. Os pequenos agricultores em Campinas. 18001850. Campinas: Área de Publicações CMU/UNICAMP, 1996.

MILLIET, Sérgio. O roteiro do café. Contribuição para o estudo da história econômica e social do Brasil. São Paulo: Hucitec, 1982.

NOGUEIRA, Lenita Waldige Mendes. Museu Carlos Gomes: Catálogo de Manuscritos Musicais. São Paulo: Arte \& Ciência/LINC, 1997.

. Música em Campinas nos últimos anos do Império. Campinas: Editora da UNICAMP, CMU, 2001.

PÁTEO, Maria Luísa de Freitas Duarte do. Bandas de música e cotidiano urbano. Dissertação (Mestrado em Antropologia Social). Instituto de Filosofia e Ciências Humanas - UNICAMP, 1997.

PENA, Eduardo Spiller. O jogo da face, astúcia escrava frente aos senhores è lei na Curitiba provincial. Curitiba: Aos Quatro Ventos, 1999.

PUPO, Celso Maria de Mello. Campinas, seu berço e juventude. Campinas: Academia Campinense de Letras, 1969. (Publicações da Academia Campinense de Letras, v. 20).

RIBEIRO, Maria Alice Rosa. Fazenda Santa Maria e Francisco Teixeira Vilela (1850-1873). IN: RIBEIRO, Suzana Barretto (org.). Arraial dos Sousas e Joaquim Egydio. Campinas, Ministério da Cultura, Lei de Incentivo Cultural, Mundo Digital Gráfica e Editora Eireli, 2016a, p.195-205.

Hercules Florence e a Fazenda Soledade. IN: RIBEIRO, Suzana Barretto (org.). Arraial dos Sousas e Joaquim Egydio. Campinas, Ministério da Cultura, Lei de Incentivo Cultural, Mundo Digital Gráfica e Editora Eireli, 2016b, p. 206-243.

Riqueza e endividamento na economia de plantation açucareira e cafeeira: a família Teixeira Vilela-Teixeira Nogueira, Campinas, São Paulo, século XIX. Estudos Econômicos, São Paulo, v. 45, n.3, p. 527-565, jul./set. 2015. 
STRUM, Daniel. O comércio do açúcar. Brasil, Portugal e Países Baixos. 1595-1630. Rio de Janeiro: Versal; São Paulo: Odebrecht, 2012.

TEIXEIRA, Paulo Eduardo. A formação das famílias livres: Campinas 1774-1850. São Paulo: Editora UNESP, 2011.

Artigo apresentado em 14/03/2016. Aprovado em 21/09/2016. 
